\section{Cytotoxicity Evaluation of Two Bis-Acryl Composite Resins Using Human Gingival Fibroblasts}

Fabiano Palmeira Gonçalves ${ }^{1}$, Gutemberg Alves², Vladi Oliveira Guimarães

Júnior ${ }^{1}$, Marco Antônio Gallito ${ }^{1}$, Felipe Oliveira ${ }^{1}$, Míriam Zaccaro Scelza ${ }^{1}$

\author{
'Department of Clinical Dentistry, \\ Laboratory of Experimental Cell \\ Culture (LECCel), UFF - Universidade \\ Federal Fluminense, Niterói, RJ, Brazil \\ ${ }^{2}$ Hospital Antônio Pedro, Molecular \\ and Cell Biology Department, \\ UFF - Universidade Federal \\ Fluminense, Niterói, RJ, Brazil
}

Correspondence: Prof Dr. Miriam Zaccaro Scelza, Rua Mario Santos Braga, 30 Centro, 24020-140 Niterói, RJ, Brasil. Tel: +55-21-99984-0270. E-mail: scelza@terra.com.br
Bis-acryl resins are used for temporary dental restorations and have shown advantages over other materials. The aim of this work was to evaluate the in vitro cytotoxicity of two bis-acryl composite resins (Protemp 4 and Luxatemp Star), obtained at 1, 7 and 40 days after mixing the resin components, using a standardized assay employing human primary cells closely related to oral tissues. Human gingival fibroblast cell cultures were exposed for $24 \mathrm{~h}$ to either bis-acryl composite resins, polystyrene beads (negative control) and latex (positive control) extracts obtained after incubation by the different periods, at $37{ }^{\circ} \mathrm{C}$ under $5 \% \mathrm{CO}_{2}$. Cell viability was evaluated using a multiparametric procedure involving sequential assessment (using the same cells) of mitochondrial activity (XT assay), membrane integrity (neutral red test) and total cell density (crystal violet dye exclusion test). The cells exposed to the resin extracts showed cell viability indexes exceeding 75\% after $24 \mathrm{~h}$. Even when cells were exposed to extracts prepared with longer conditioning times, the bis-acryl composite resins showed no significant cytotoxic effects ( $p>0.05)$, compared to the control group or in relation to the first $24 \mathrm{~h}$ of contact with the products. There were no differences among the results obtained for the bis-acryl composite resins evaluated 24 h, 7 days and 40 days after mixing. It may be concluded that the bis-acryl resins Protemp 4 and Luxatemp Star were cytocompatible with human gingival fibroblasts, suggesting that both materials are suitable for use in contact with human tissues.
Key Words: biocompatibility, fibroblasts, temporary dental restoration.

\section{Introduction}

Dental temporary restorations are used during the period between tooth preparation and the installation of permanent restorations. The aim of temporary restorations is to preserve teeth function, abutment relationships, pulpal integrity and periodontal health (1). However, in routine clinical practice, problems may occur when a temporary resin restoration is used to rebuild a tooth that requires subgingival margin preparation, or to establish the soft tissue profile around a dental implant platform or under a prosthetic area (2). Because of poor marginal adaptation and the usual surface roughness of temporary restorations, the cytotoxic effects of leached resin monomers may lead to tissue necrosis and plaque formation in the adjacent areas (2).

Based on how they are converted from plastic to solid elastic masses, temporary restoration materials have been classified as: (i) chemically activated acrylic resins; (ii) heat activated acrylic resins; (iii) light activated acrylic resins; and (iv) dual (light and chemically activated) acrylic resins (3). Furthermore, there are several types of acrylic resin materials available for temporary restorations, including polymethyl methacrylate resins, polyethyl methacrylate resins, as well as other types or combinations of unfilled methacrylate resins and composite resins (4). Powder and liquid resins based on polymethyl methacrylate (PMMA) traditionally represent the main choice for temporary restoration materials, even though their disadvantages include significant polymerization shrinkage and an exothermic setting reaction. In addition, monomer release from PMMA can cause irritation and the material usually has a unpleasant odor (4).

Materials based on bis-acryl have been employed as an alternative in the production of temporary restorative materials They have advantages such as easier manipulation, due to the use of a cartridge-based dispensing system which enables accurate preparation of a consistent mixture, as well as low polymerization shrinkage and a less exothermic reaction, implying in minimal pulp irritation (5). Furthermore, compared to traditional PMMA resins, the bis-acryl composite resin provides better contour and marginal adaptation, improved finishing aspects and greater microhardness (5).

The literature reports few in vitro studies on the cytotoxicity of bis-acryl composite resins, despite the fact that these materials contain methacrylate, which presents a well-known cytotoxicity (6-8). In the present work, the aim was to assess the in vitro responses of human gingival fibroblasts (HGF) to two such resins, Protemp 4 (3M ESPE, Sumaré, SP, Brazil) and Luxatemp Star (DMG, Hamburg, 
Germany), by simultaneously analyzing three different cell viability parameters: mitochondrial activity, membrane integrity and cell proliferation.

\section{Material and Methods}

This work is part of a project approved by the Antonio Pedro Hospital / University Federal Fluminense Committee of Research Ethics (CAAE 45480315.1.0000.5243). The gingival tissues used for the cell culture came from prosthetic surgery performed in the Periodontology and Dentistry Clinic of UFF - Universidade Federal Fluminense

\section{Sample Preparation}

The bis-acryl composite resins (Protemp 4 and Luxatemp Star) were prepared as per the manufacturers' instructions (Table 1). Test samples consisting of conditioned media were obtained according to ISO 7405:2008 (9). Briefly, $0.2 \mathrm{~g}$ of fragments of each resin, $2 \mathrm{~mm}$ thick and a total surface area of $6 \mathrm{~cm}^{2}$, were completely immersed in $1 \mathrm{~mL}$ of serum-free Alpha-MEM (Gibco, Cergy-Pontoise, France) on Falcon polystyrene tubes (Corning Inc, New York, NY, USA) and incubated for $24 \mathrm{~h}$ at $37^{\circ} \mathrm{C}$ in a humidified chamber. Different test media were obtained in the form of extracts of each bis-acryl composite resin removed after 1,7 or 40 days, following renewal of the medium every day, in order to simulate the effects of gingival crevicular fluid in washing the material in the patient's mouth. Human gingival fibroblasts (HGF) came from the Laboratory Experimental of cell culture of the Universidade Federal Fluminense, as described above. Cell cultures (2nd passage), cultivated in DMEM containing 10\% fetal bovine serum (GIBCO Invitrogen, Grand Island, NY, USA) and 1\% antibiotic, at $37{ }^{\circ} \mathrm{C} / 5 \% \mathrm{CO}_{2}$, were seeded at a density of $3 \times 10^{4}$ cells $\mathrm{mL}^{-1}$ in wells of a 96-well plate and incubated for $24 \mathrm{~h}$ at $37^{\circ} \mathrm{C} / 5 \% \mathrm{CO}_{2}$. Negative control groups were composed of cells plus culture medium (Alpha-MEM) and polystyrene plus culture medium. Extracts of latex fragments on culture medium were the positive control group, since its consistent cytotoxicity in ISO-based assays was previously demonstrated (10). Each condition was tested using three replicates in each of the three different assays.

\section{Multiparametric In Vitro Assay}

Cytotoxicity was assessed in vitro according to international standards for the evaluation of dental materials (9), employing a multiparametric assay kit (In Cytotox, Xenometrix, Allschwil, Swittzerland), which sequentially evaluates three different cell viability parameters using the same cell culture (11)Vancouver, BC, Canada. For this purpose, human gingival fibroblasts (HGF) obtained from the Experimental Cell Culture Laboratory (LECCel) were subcultured for $24 \mathrm{~h}$ at $37^{\circ} \mathrm{C}$ on 96 -well culture plates, at an initial cell density of 10,000 cells per well and were subsequently exposed to the test media (prepared as described in the previous section) for $24 \mathrm{~h}$.

\section{Mitochondrial Dehydrogenase Activity}

Mitochondrial dehydrogenase activity was measured by means of the XT assay after exposure of HGF to the test media. This test is based on the ability of mitochondrial enzymes in the metabolically active cells to reduce 2,3-bis (2-methoxy-4-nitro-5-sulfophenyl)-2H-tetrazolium-5carboxanilide (XTT) molecules to a soluble formazan salt, detectable by its absorbance at $480 \mathrm{~nm}$, as measured using a UV-Vis microplate reader (Synergy II, BioTek Inc., Winooski, VT, USA).

\section{Membrane Integrity}

The same cells used for the XTT test were washed and submitted to the neutral red uptake test (NR) to determine the levels of viable cells by means of their membrane integrity. The NR vital dye is incorporated by endocytosis and is preferentially accumulated in the lysosomes of intact viable membrane cells. After $3 \mathrm{~h}$ of exposure to the dye, the

Table 1. Constituents of bis-acryl composite resins

\begin{tabular}{|c|c|c|}
\hline $\begin{array}{l}\text { Material and } \\
\text { manufacturer }\end{array}$ & Composition & Preparation mode \\
\hline $\begin{array}{l}\text { Protemp } 4 \text { (3M } \\
\text { ESPE, Brazil) }\end{array}$ & $\begin{array}{c}\text { Catalyst Paste: Ethanol, 2,2'-[(1-methylethylidene) bis(4,1-phenyleneoxy)] bis-, diacetate } \\
\text { Benzyl-phenyl-barbituric acid } \\
\text { Silane trated silica } \\
\text { Tert-butyl peroxy- 3,5,5-trimethylhexanoate } \\
\text { Base Paste: dimethacrylate (BISEMA 6), silane-treated amorphous silica, reaction } \\
\text { products of 1,6-diisocyanatohexane with 2-[(2-methacryloyl) ethyl] 6- hydroxyhexanoate } \\
\text { and 2- hydroxyethyl mathacrylate (DESMA), silane-treated silica }\end{array}$ & $\begin{array}{l}\text { The product is mixed } \\
\text { automatically using } \\
\text { the cartridge. }\end{array}$ \\
\hline $\begin{array}{l}\text { Luxatemp Star } \\
\text { (DMG, Germany) }\end{array}$ & $\begin{array}{l}\text { Glass filler in a matrix of multifunctional methacrylates; catalysts, stabilizers and additives. } \\
\text { Free of methyl methacrylate. Total filler volume: } 44 \% \text { w. } \%=24 \text { vol. } \% \text { (0.02 to } 1.5 \mu \mathrm{m})\end{array}$ & $\begin{array}{l}\text { The product is mixed } \\
\text { automatically using } \\
\text { the cartridge. }\end{array}$ \\
\hline
\end{tabular}

*Information obtained from data provided by the manufacturer. 
cells were fixed and the NR was measured as the optical density (O.D.) of the supernatant at $540 \mathrm{~nm}$, which may be directly related to the rate of viable cells.

\section{Cell Density}

, The fixed cells were washed after NR test and total density of the adhered cells was estimated using the crystal violet dye exclusion test (CVDE). The cells were treated with concentrated crystal violet dye (CV) and after exhaustive washing, the dye was extracted with a solution containing acetic acid and ethanol. As CV binds preferentially to DNA, the $0 . D$. at $540 \mathrm{~nm}$ of the dye extracted after washing was directly related to the total amount of cells in each well.

\section{Statistical Analysis}

Statistical analysis was carried out using GraphPad Prism 5 software (GraphPad, San Diego, CA, USA). The mean values and standard deviations were calculated for each group and the normality of the variable distributions was evaluated using D'Agostino's test.

Nonparametric analysis of variance (Kruskal-Wallis test) with the Dunn post-hoc test was performed for comparison among groups. A significance level of 5\% was set for all tests.

\section{Results}

Figure 1 shows the cell viabilities obtained in the three different assays, following exposure of the cells to the $24 h, 7$ day and 40 day bis-acryl composite resin extracts, expressed as percentages of the values for the experimental control (cells exposed to culture media without extraction). In the whole assay, latex remained cytotoxic as expected after exposure of cells to $24 \mathrm{~h}$ extracts, even after daily sequential washing by 7 or 40 days, even though the toxic effects were significantly reduced with washing $(p<0.05)$, since cell survival increased up to twenty times from 1 to 40 days, as demonstrated by the XTT assay (Fig. 1A). As shown in Figure 1 , panels $A, B$ and $C$, the bis-acryl composite resins presented no cytotoxic effects after mixing. This occurred regardless of the extraction time and washing, and according to all three methods, since exposure to all the extracts resulted in survival rates $>75 \%$ of the control group. No significant differences were found between both materials $(p>0.05)$.

\section{Discussion}

Dental materials include a wide range of different monomers and additives. The complex chemical composition and incomplete monomer-to-polymer conversion may result in leaching of components from resin-based restorative materials into the oral environment (12). This in turn can lead to allergic reactions such as burning sensations in the mouth; red, swollen and painful gums, oral vesicles and ulcers (13). Hence, it is important to evaluate the cytotoxic effects of dental materials not only in epithelial cells but also in gingival fibroblasts (14). Consequently, human gingival fibroblasts (HGFs) were employed in the current study to evaluate the cytotoxicity of the two selected bis-acryl composite resins from two different brands available on the international market. In order to evaluate the in vitro biocompatibility of a material,

\section{(A)}

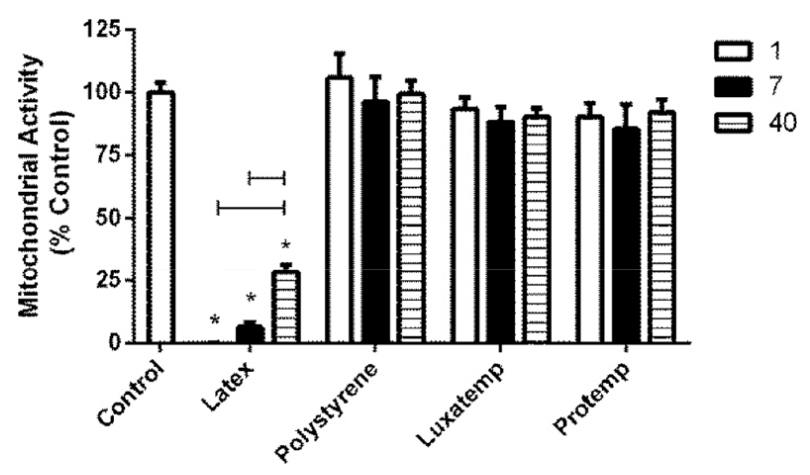

B

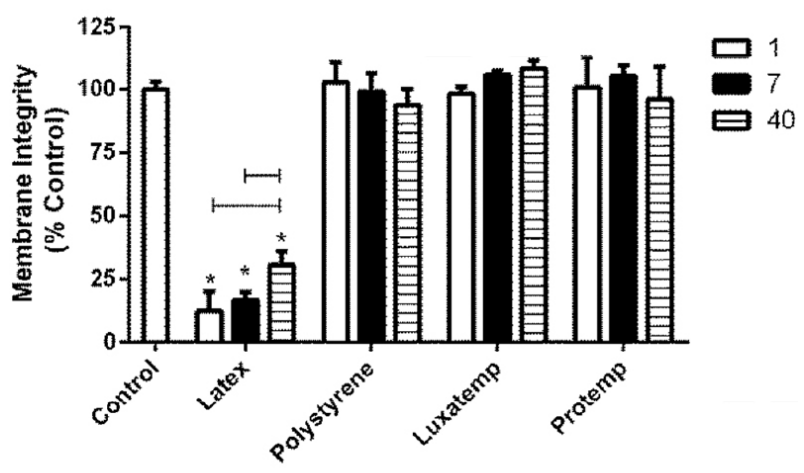

C

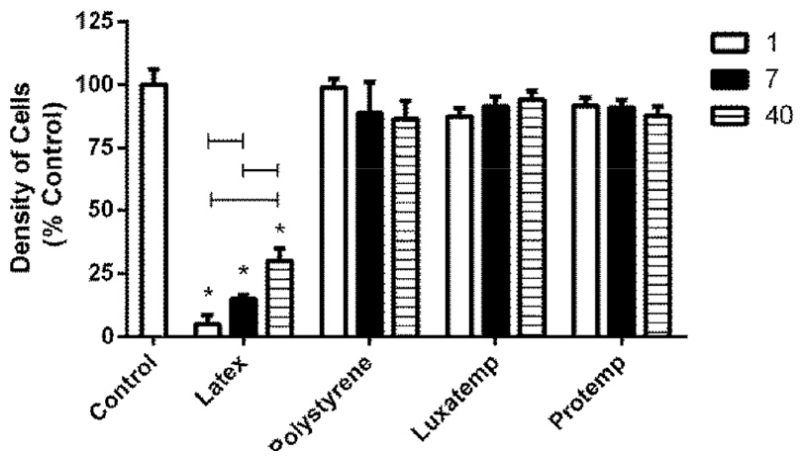

Figure 1. Cytotoxicity assay. Cytocompatibility assessement of bis-acryl composite resins on HGF by XTT (A), Neutral Red (B) and Crystal Violet Dye Exclusion (C) tests, expressed as mean percentage of control (cells exposed to culture medium). Extracts of polystyrene beads and latex fragments were used as negative and positive controls, respectively. *Statistically different from all other groups in the same experimental time $(p<0.05)$. Lines between bars indicate significant differences among time points $(\mathrm{p}<0.05)$. 
cytotoxicity testing should be performed with cell types suitable for mimicking the real interaction between the material and exposed tissues (15). The literature mentions various different cell types for this purpose. Normal diploid human cells from primary cell cultures are the most appropriate for toxicity testing of materials intended for human use (16). Furthermore, primary cells are more sensitive in cytotoxicity tests and ensure the reproducibility of cell metabolism (17). In the specific case of Human Primary Gingival Fibroblasts, other authors have already demonstrated that these cells are adequately sensible to methyl methacrylate on a dose-response basis (7).

In vitro tests may be very useful in determining the biological effects of dental materials (18). Given the advantages of in vitro tests for assessment of the cytotoxicity of dental products and the scientific acceptability of the obtained results, multiparametric testing, i.e., the simultaneous assessment of different cell viability parameters on the same assay, may be an option for the evaluation of bis-acryl resins (8). The combined use of in vitro tests, animal tests and human trials constitute an ideal combination (19). In recent decades, in vitro cell cultures became widely used in the medical science research field and are considered effective for the routine toxicity testing of many materials, prior to further in vivo studies. In vivo tests, using animals in the laboratory, have limitations that are not only due to the opposition of animal rights groups, but also due to ethical and economic considerations. It should be noted that validation studies found a high correlation (97\%) among toxicity tests conducted in vitro and in vivo (19).

In this work, the extraction steps for the indirect exposure of cells was performed as recommended by the IS07405:2008 standard ( $24 \mathrm{~h}$ ), but also for longer times (up to 40 days of extraction), in order to assess the eventual long-term release of substances with cytotoxic effects. Therefore, the extraction media were changed on a daily basis, aiming to avoid the possible accumulation of toxic substances in the confined space of a 96-well plate, since in the dilution of them in the mouth is probably achieved by constant wetting of the oral tissues by saliva.

Interim fixed dental prostheses are crucial for the protection of dental surfaces until the final restoration is cemented into position. These prostheses may be short-term, until the conclusive restoration is fabricated, or of long-term, when a patient needs a longer course of treatment, like in complete mouth prosthodontic treatments, alveoloplasty, orthodontic or endodontic procedures and oral surgery. Long-term interim fixed dental prostheses require materials that have color stability and mechanical properties that ensure adequate fracture strength and sufficient dimensional and marginal stability.
Bis-acryl reinforced with glass fiber exhibited the least marginal discrepancy in long-term use $(4,20)$. This work tested a reasonably long 40-day period in order to simulate clinical conditions and the likely periods for which bis-acryl provisional restorations may remain in contact with the gum tissue, ranging from a few days to several months. Interestingly, the results indicate no cytotoxicity for both resins at $24 \mathrm{~h}$ and, consequently, no toxicity was expected after 40 days with washing, as confirmed by the results. It is important to notice that materials with extreme toxic effects might continue to release soluble toxic agents and cause cell death, as in the case of the positive control chosen for this study (latex fragments), even after daily washing during long-term extraction. The difference in the behavior of the studied resins and the positive control reinforces the conclusion that both materials are biocompatible.

In a systematic review, it was reported that acrylic resins are generally cytotoxic due to the presence of methyl methacrylate and can cause hypersensitivity (21). Nevertheless, particularly in relation to Luxatemp Star, there is lack of scientific studies on its cytotoxicity and eventual release of toxic substances. Other resins containing methacrylate have shown cytotoxicity when tested in fibroblast cell cultures for $24 \mathrm{~h}(7,22)$. In this study, for all the used exposure times, the bis-acryl resins did not affect cell viability, according to the three assays (XT, NR and (DVE). Hence, the tested materials did not exhibit any cytotoxicity, even for cells exposed to the extract obtained after the first $24 \mathrm{~h}$ of leaching, which was likely to contain the highest concentrations of any potentially cytotoxic substances. This difference may be ascribed to the use of the MTT test in earlier studies. The XT assay, used in this study, has advantages over the MTT assay as used it does not need an extended incubation time, offers higher sensitivity and requires less manipulation because the solubilization step is eliminated, so the risk of error is lower than in the MTT assay (23).

In an evaluation of the cytotoxicity of Protemp 3 Garant (3M ESPE, ESPE Dental-Medizin, Seefeld, Germany), it was found that this material was not cytotoxic towards L929 fibroblasts, compared to a control group (cells plus culture medium) (24). It is important to notice that the brand tested in the present work, Protemp 4, is a new formulation (the latest available on the market) and there is a difference between the chemical compositions of these materials, even though the exact difference on constituent monomers of the base paste and catalyst between these formulations is not clarified by the manufacturer. Nevertheless, the present study, conducted using HGF primary cells, shows similar cytocompatibility between Protemp 4 and the one reported in the previous evaluation of Protemp 3 Garant (24). Possibly, the lack of cytotoxicity of the bis-acryl 
composite resin may be correlated to the findings of Schulz et al. (25) in a study of the elution of provisional resin composite materials on saliva, where it was observed no release of monomers and toxic products from Protemp 3 , after elution times as long as 28 days.

In agreement with the present study, a previous work using a different methodology found that the use of acrylic resin in provisional restorations caused no cytotoxic effects in human gingival fibroblasts within $72 \mathrm{~h}$, considering the effects on cytokines and growth factors (16). However, the frequent reports in the scientific literature of monomers leaching out of different types resins $(6,12,13,18,21,22)$, particularly methyl methacrylate derivatives, which may cause cytotoxicity in contact with human cells, stimulate the assessment of cytotoxicity of all members of this group of dental materials. In this context, the present results support the need to carry out biocompatibility assessments of dental materials employing human primary cell models, in order to ensure safe extrapolation of results to the clinical environment. The findings indicated high biocompatibility of Protemp 4 and Luxatemp Star with human gingival fibroblasts, suggesting that these products should be suitable for use close to gingival tissue. detectable cytotoxicity to human gingival fibroblasts.

\section{Resumo}

Resinas bisacrilicas são usadas em restaurações dentárias provisórias e têm mostrado vantagens em relação a outros materiais. 0 objetivo deste trabalho foi avaliar a citotoxicidade in vitro de duas resinas compostas bisacrílicas (Protemp 4 e Luxatemp Star), obtidas após 1, 7 e 40 dias da mistura com os componentes da resina, usando um ensaio padronizado empregando células primárias humanas fortemente relacionadas aos tecidos orais. Culturas de células de fibroblastos gengivais humanos foram expostas por $24 \mathrm{~h}$ aos extratos das resinas bisacrílicas, esferas de poliestireno (controle negativo) e látex (controle positivo), obtidos após diferentes periodos de incubação, a $37^{\circ} \mathrm{C}$ e com 5\% C02. A viabilidade celular foi avaliada usando procedimentos multiparamétricos que envolvem a avaliação sequencial (usando as mesmas células) da atividade mitocondrial (ensaio XTT), a integridade de membrana (teste do vermelho neutro) e a densidade celular total (teste de exclusão do corante cristal violeta). As células expostas aos extratos mostraram viabilidade celular acima de $75 \%$ depois de $24 \mathrm{~h}$. Mesmo quando as células foram expostas aos extratos com aumento do tempo de condicionamento, as resinas bisacrilicas não apresentaram efeitos citotóxicos significativos $(p<0,05)$, comparadas ao grupo controle ou em relação às primeiras $24 \mathrm{~h}$ de contato com os produtos. Não houve diferença entre os resultados obtidos para as resinas bisacrílicas avaliadas entre as $24 \mathrm{~h}, 7$ e 40 dias depois da mistura. Concluímos que as resinas bisacrílicas Protemp 4 e Luxatemp Star foram citocompativeis com os fibroblastos gengivais humanos, sugerindo que ambos materiais são adequados para uso em contato com tecidos humanos.

\section{References}

1. Lee J, Lee $\mathrm{S}$. Evaluation of add-on methods for bis-acryl composite resin interim restorations. J Prosthet Dent 2015;114:594-601.

2. Borzangy S, Labban $N$, Windsor $\amalg$. Effects of interim acrylic resins on the expression of cytokines from epithelial cells and on collagen degradation. J Prosthet Dent 2013;110:296-302.

3. Vahidi F. The provisional restoration. Dent Clin North Am 1987;31:363381.

4. Burns DR, Beck DA, Nelson SK. A review of selected dental literature on contemporary provisional fixed prosthodontic treatment: Report of the Committee on Research in Fixed Prosthodontics of the Academy of Fixed Prosthodontics. J Prosthet Dent 2003;90:474-497.

5. Young HM, Smith CT, Morton D. Comparative in vitro evaluation of two provisional restorative materials. J Prosthet Dent 2001;85:129-132.

6. de Andrade Lima Chaves C, Machado AL, Vergani CE, de Souza RF, Giampaolo ET. Cytotoxicity of denture base and hard chairside reline materials: A systematic review. J Prosthet Dent 2012;107:114-127.

7. Souto-Lopes M, Azevedo A, Teixeira A, Bastos-Aires D, Lordelo J, Pérez-Mongiovi D. Cytotoxicity of acrylic based resin compounds in a human gingival fibroblast cell line. Rev Port Estomatol Med Dent e Cir Maxilofac 2013;54:87-90.

8. Wataha JC. Principles of biocompatibility for dental practitioners. J Prosthet Dent 2001;86:203-209.

9. ISO 7405:2008 (2008) Dentistry - Preclinical Evaluation of Biocompatibility of Medical Devices Used in Dentistry - Test Methods for Dental Materials. ISO 7405:2008.

10. Lourenço ES, Côrtes J, Costa J, Linhares ABR, Alves G. Evaluation of commercial latex as a positive control for in vitro testing of bioceramics. Key Engin Mat 2015;631:357-362.

11. De-Deus G, Canabarro A, Alves G, Linhares A, Senne MI, Granjeiro JM. Optimal cytocompatibility of a bioceramic nanoparticulate cement in primary human mesenchymal cells. J Endod 2009;35:1387-1390.

12. Van Landuyt KL, Nawrot T, Geebelen B, De Munck J, Snauwaert J, Yoshihara $\mathrm{K}$, et al.. How much do resin-based dental materials release? A meta-analytical approach. Dent Mater 2011;27:723-747.

13. Rashid H, Sheikh Z, Vohra F. Allergic effects of the residual monomer used in denture base acrylic resins. Eur J Dent 2015;9:614-619.

14. Hashimoto $Y$, Tanaka J, Suzuki K, Nakamura M. Cytocompatibility of a tissue conditioner containing vinyl ester as a plasticizer. Dent Mater J 2007;26:785-791.

15. Huang F-M, Li Y-C, Lee S-S, Chang Y-C. Cytotoxicity of dentine bonding agents on human pulp cells is related to intracellular glutathione levels. Int Endod J 2010;43:1091-1097.

16. Labban N, Song F, Al-Shibani N, Windsor L. Effects of provisional acrylic resins on gingival fibroblast cytokine/growth factor expression. J Prosthet Dent 2008;100:390-397.

17. Schmalz G. Use of cell cultures for toxicity testing of dental materials - advantages and limitations. J Dent Suppl 2 1994;22:S6-S11.

18. Huang FM, Chang YC. Cytotoxicity of resin-based restorative materials on human pulp cell cultures. Oral Surg Oral Med Oral Pathol Oral Radiol Endod 2002;94:361-365.

19. Rovida C, Asakura S, Daneshian M, Hofman-Huether H, Leist $M$, Meunier $L$, et al.. Toxicity testing in the 21st century beyond environmental chemicals. ALTEX 2015;32:171-181.

20. Peñate $L$, Basilio J, Roig M, Mercadé M. Comparative study of interim materials for direct fixed dental prostheses and their fabrication with CAD/CAM technique. J Prosthet Dent 2015;114:248-253.

21. Mallikarjuna AV. Cytotoxicity of acrylic resin : a review. J Dent Med Sci 2014;13:7-9.

22. Lai YL, Chen YT, Lee SY, Shieh TM, Hung SL. Cytotoxic effects of dental resin liquids on primary gingival fibroblasts and periodontal ligament cells in vitro. J Oral Rehabil 2004;31:1165-1172.

23. Goodwin CJ, Holt SJ, Downes S, Marshall NJ. Microculture tetrazolium assays: a comparison between two new tetrazolium salts, XTT and MTS. J Immunol Methods 1995;179:95-103.

24. Ulker $M$, Ulker HE, Zortuk M, Bulbul M, Tuncdemir AR, Bilgin MS. Effects of current provisional restoration materials on the viability of fibroblasts. Eur J Dent 2009;3:114-119.

25. Schulz SD, Laquai T, Kümmerer K, Bolek R, Mersch-Sundermann $\mathrm{V}$, Polydorou 0 . Elution of monomers from provisional composite materials. Int J Polym Sci 2015;2015:1-7. 